\title{
A Conceptual Model for Semarang City Sustainability
}

\author{
Ivan Syamsurizal ${ }^{1}$, Mufti P. Patria ${ }^{2}$, Raldi H.S. Koestoer ${ }^{3}$, and Djoko Harmantyo ${ }^{4}$ \\ \{ivansyam@yahoo.com¹,mpatria@gmail.com², ralkoest@yahoo.co.uk ${ }^{3}$, \\ djokoharmantyo@yahoo.com ${ }^{4}$ \} \\ School of Environment Science, Universitas Indonesia ${ }^{1}$, Department of Biology Faculty of \\ Mathematics and Natural Science, Universitas Indonesia ${ }^{2}$, School of Environment Science, Universitas \\ Indonesia ${ }^{3}$, Department of Geography Faculty of Mathematics and Natural Science, Universitas \\ Indonesia ${ }^{4}$
}

\begin{abstract}
Coastal site is a very strategic area, proven by the fact that $70 \%$ of big cities in the world are located in coastal areas or precisely in coastal areas. Coastal are also has a high level of sensitivity to natural phenomena such as tsunami, tidal floods, strong sea winds, or abrasion. Semarang City is one of the coastal cities with high vulnerability, especially from the tidal flood caused by rising sea levels and land subsidence. Kota Lama/historical area is an area directly adjacent to the coast of Semarang City. This area is the first site affected by the tidal flood that often occurs in Semarang City. This research aims to provide an alternative model for the sustainability of cities in the coastal area through a protection approach to historic areas as a factor of resilience to the city. The method used to produce the model is overlaying technique using ArcGIS software. The variables used in this study are physical and social factors. The physical factors consist of the slope of the coast, the maximum tidal range, average wave height, sea-level rise, beach geomorphology, coastline changes, and land subsidence. Social factors consist of population density, land use, population age, and education level. All variables are given a weight according to their respective criteria by the weighted overlay method. The next step is the process of adding the weights of each variable using simple mathematical operations using the sum tools. The final stage to obtain the vulnerability index distribution zone is carried out reclassification to show its spatial distribution. The results show that the Kota Lama Region is proven to have contributed to the formation of City resilience.
\end{abstract}

Keywords: Model, Coastal, Kota Lama/historical area, Resilience, Land Subsidence

\section{Introduction}

Coastal is a very strategic area because of its rich natural resources and the potential value of its spatial functions. Coastal Areas is a transitional area between terrestrial and marine ecosystems which are affected by changes in land and sea [1]. The Coastal environment is an environment very dynamic with various land uses which is very complex [2], [3], [4]. Almost half of the world's major cities have a population density up to 2.6 times denser than the entire island where the city is located [5]. The high density and human activity in the coastal area, in this case, the coastal city, put significant pressure on the existence of the coastal city itself in addition to the pressure from nature because of its position was vulnerable to natural phenomena.

Tidal flood is a phenomenon that often occurs in coastal areas, which is indicated by a rise in sea levels that are local and due to global impacts. Tidal floods inundated coastal areas or places 
lower than the high tide level [6]. Tidal floods are a threat that occurs almost every rainy season in the coastal areas. This disaster has an impact on the lives of people living in coastal areas.

Semarang City is one of the coastal cities in Indonesia which has a high vulnerability to tidal flood disasters in addition to certain areas with a high enough slope vulnerable to landslides. The impact of sea-level rise on the coast of Semarang is the existence of tidal flooding which continuously expands its expanse. As research by Suhelmi et al. [7], it was found that the rate of areas inundated on the coast of Semarang by tidal flooding was expected to increase from $3,697.1$ ha assuming an increase in sea level optimistic scenario $(18 \mathrm{~cm})$ to $5,084.2$ ha with a pessimistic scenario $(58 \mathrm{~cm})$ in 2100 .

Research conducted by Pellikka et al [8] in the Gulf of Finland suggests that, according to the highest sea level scenario, the level of sea-level rise will be even higher than land level in 2100, so that coastal area planning requires detailed knowledge of future flood risks, in addition to long-term changes are also variations in short-term sea level.

Some research has been carried out, namely: Nugroho [9], Miladan [10], Suhelmi [11], Fauziah [12], Yesiana et al. [13], overall, also said that the Coastal of Semarang City has a high vulnerability to disasters especially related to tidal flooding and land subsidence. Looking at the vulnerabilities faced by the City of Semarang, naturally various and appropriate alternatives need to be developed to support efforts to handle and prevent the effects of the vulnerability so that the sustainability of the City of Semarang can be maintained.

Kota Lama/historic area is an area directly adjacent to the coast of Semarang City. This area is the first area affected by the tidal flood that often occurs in Semarang City. Maintaining the sustainability of this region means simultaneously maintaining the sustainability of Semarang City as a whole. This research aims to provide an alternative model of urban sustainability in coastal areas through a protection approach to historic areas as a factor of resilience to the city.

\section{Method}

\subsection{Study Area}

Study area in this research is located in The Semarang City where most of it is located in the area around the Kota Lama of Semarang, which is administratively located in 5 sub-districts, namely: Central Semarang, South Semarang, North Semarang, Candisari, and Gajahmungkur subdistrict, as shown in Figure 1. 


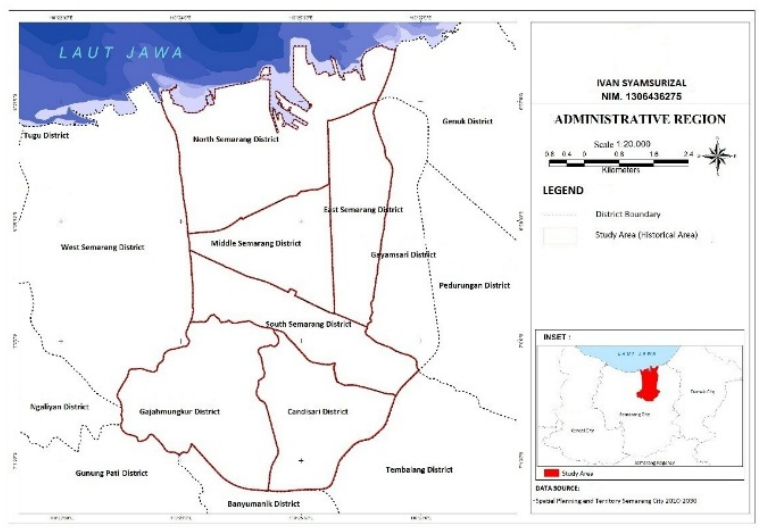

Fig. 1. Study Area

Source: Syamsurizal [14]

\subsection{Variabel and Data Analysis}

The concept of resilience has a very close relationship with the concept of vulnerability, meaning that resilience can be formulated when the vulnerability has been identified and analyzed appropriately. Coastal vulnerability generally consists of economic vulnerability, social vulnerability, and environmental vulnerability. In this research, vulnerability analysis is only done on social vulnerability and environmental vulnerability, while the economic vulnerability is considered as the impact arising from the two vulnerabilities earlier.

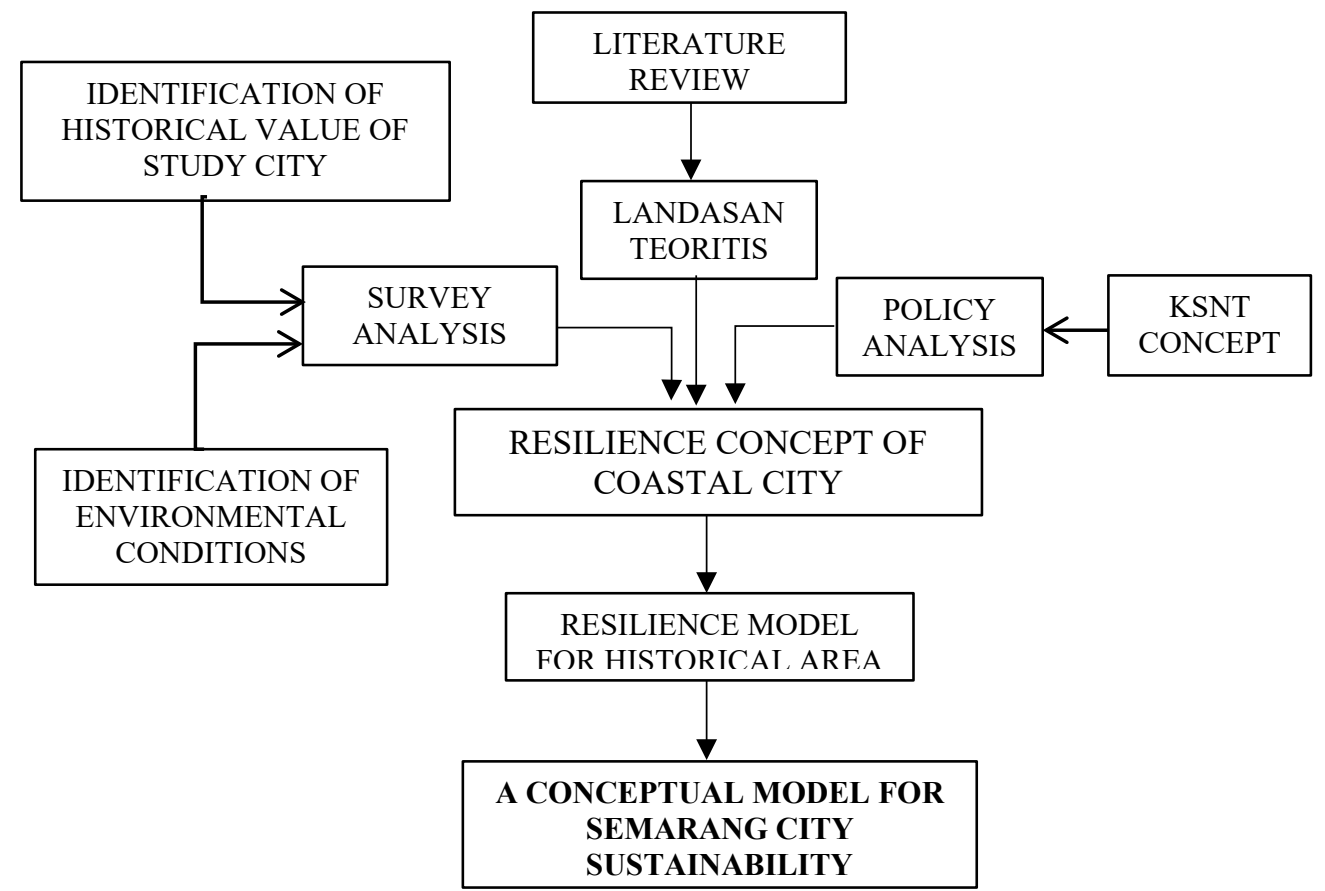

Fig. 2. Conceptual Model for Historical City of Semarang 
According to the Figure 2, the KSNT (Specific National Strategic Area)-based development approach is one of the strategic opportunities for the realization of sustainable coastal cities because in its implementation it can encourage the involvement of all components of both the community and institutions even at home and abroad as well as international institutions. The development of KSNT which has great opportunities to be implemented in coastal cities in Indonesia is the KSNT site or world heritage because many coastal cities have been formed for a long time and experienced various times or cultural orders and left various kinds of high-value and world-class urban architecture works. This approach can be an alternative for coastal cities to carry out the development of their cities, and at the same time make efforts to rescue the pressure that can damage the city, so that in turn will encourage its sustainability.

Based on the data distribution of cultural heritage buildings and urban spaces which are considered to have historical value for the city of Semarang, most are located in the area around the Old City of Semarang, which is administratively located in 5 subdistricts, namely: Central Semarang, South Semarang, North Semarang, Candisari, and Gajahmungkur.

Referring to Brenkert et al. [15], the resilience built in this research adopts the Vulnerability Resilience Indicator Prototype (VRIP) model using 3 (three) constituent factors, namely: Exposure, Sensitivity, and Adaptive Capacity. In detail, the data requirements related to research variables will be obtained as explained in Table 1.

Table 1. Types and Methods of Obtaining Spatial Data

\begin{tabular}{clcc}
\hline NO & \multicolumn{1}{c}{ Types of Data } & $\begin{array}{c}\text { How to Obtain } \\
\text { Data }\end{array}$ & Data Source \\
\hline 1. & Slope of beach & $\begin{array}{c}\text { Interpolation } \\
\text { Interpretation }\end{array}$ & $\begin{array}{c}\text { Google } \\
\text { Navy's Hydrological and } \\
\text { Oceanographic Service } \\
\text { Navy's Hydrological and } \\
\text { Oceanographic Service }\end{array}$ \\
3. & Sea level rise & Interpretation & Interpretation \\
4. & Geology & $\begin{array}{c}\text { Regional Disaster Management } \\
\text { Agency of Semarang CIty } \\
\text { History and Research Books }\end{array}$ \\
5. & Change in Coastline & $\begin{array}{c}\text { Sketches } \\
\text { Interpretation } \\
\text { and Calculation }\end{array}$ & $\begin{array}{c}\text { Regional Disaster Management } \\
\text { Agency of Semarang City and } \\
\text { analysis result }\end{array}$ \\
\hline
\end{tabular}

(Source: Data Processing, 2019)

Based on Table 1, the type of beach slope data is obtained from DEM data downloaded at https://earthexplorer.usgs.gov/, the data is processed by interpolation techniques which are processed using ArcGIS software. Besides, one way to obtain data is to use interpretation techniques. Interpretation is a way of understanding a phenomenon or phenomenon that occurs by using illustrative media that are not only statements in the form of facts. The interpretation used in this study is in the form of interpretation with a spatial approach (spatial) by understanding the phenomena or phenomena that occur using media in the form of maps. While the calculation technique used in the form of calculations from the tables generated based on the results of processing on the map data. 
The interpolation procedure used is interpolation with the finite difference interpolation technique approach. The principle of the method is the assumption that the surface of the specified area obeys some differential equations, both in whole and partially. This equation is then estimated with finite differences and iterative. For example, a problem finding $\mathrm{z}$ functions, such as:

$$
\frac{\delta^{2} z}{\delta x^{2}}+\frac{\delta^{2} z}{\delta y^{2}}=0
$$

In a region, and $z\left(x \_i, y \_i\right)=0$ on the boundary line. This equation is the LaPlace equation; and estimates of the limited difference of this equation are:

$$
z_{i j}=\frac{\left(z_{i-1 j}+z_{i+1 j}+z_{i j-1}+z_{i j+1}\right)}{4}
$$

Whereas, $\mathrm{z}_{\mathrm{ij}} \mathrm{ij}$ is the value in cell $\mathrm{ij}$. As an effect, this equation requires a value from a point which is the average of the values of 4 points adjacent to that point, which results in a smooth surface [16]. Thus, the resulting surface has no absolute value, or a maximum and minimum relative value other than the values of the predetermined boundaries [17].

The variables used in this study are social and physical factors. Social factors consist of population density, change in the function of the region, and education level. These social factors were obtained from the Central Bureau of Statistics of Semarang City. While the physical factors used to consist of the slope of the coast, the maximum tidal range, average wave height, sea-level rise, beach geomorphology, coastline changes, and land subsidence. These physical factors were obtained from the Central Bureau of Statistics of Semarang City, Navy's Hydrological and Oceanographic Service, History and Research Books.

\begin{tabular}{|c|c|c|c|c|}
\hline \multicolumn{5}{|c|}{ Density } \\
\hline Area Classification & Low & Medium & High & Very High \\
\hline Population density & $\begin{array}{l}<150 \\
\text { people/ha }\end{array}$ & $151-200$ people/ha & $\begin{array}{l}201-400 \\
\text { people/ha }\end{array}$ & $>400$ people/ha \\
\hline $\begin{array}{l}\text { Reduction of land } \\
\text { requirements }\end{array}$ & - & - & $15 \%($ maximum $)$ & $30 \%$ (maximum) \\
\hline
\end{tabular}

Table 2. The Reduction Factor for Land Requirements for Environmental Facilities Based on Population

Source: Syamsurizal [14]

All variables are given a weight according to their respective criteria by the weighted overlay method. The next step is the process of adding the weights of each variable using simple mathematical operations using the sum tools. The next stage is the filtering process using the query method to group regions that have high, medium, and low weights.

The final stage to obtain the vulnerability index distribution zone is carried out reclassification to show its spatial distribution. The classifications used are high, medium and low grade. Tidal flood areas were obtained from the overlay between elevation data obtained from DEM data (2018) and the ground level elevation data (2018) obtained from the Regional Disaster Management Agency of Semarang City. 


\section{Result And Discussions}

Government policy in the development of coastal areas mandated in Law no. 1 of 2014 and Government Regulation No. 26 of 2008 [18] Concerning National Spatial Planning as well as several other regulations, directing the development of coastal cities to be more optimal in utilizing sea space can also utilize various city potentials, one of which is the development of a Specific National Strategic Area (KSNT) approach. The KSNT definition is an area related to state sovereignty, environmental control, and/or world heritage sites, whose development is prioritized for national interests.

The KSNT concept is applied to the coastal sustainability of the City of Semarang in particular, and the City of Semarang as a whole. This research will produce a model called the Area Resilience Index Model (ARIM). This research is expected to be a renewal in the field of spatial planning and can be a reference in disaster mitigation for future tidal floods. Research on the vulnerability of coastal areas has been done by many researchers before, but from some of these researchers conducted a study of vulnerability of coastal areas to tidal flooding with GIS analysis with overlay analysis, height analysis using DEM and comparing it to sea-level rise sea-level values, and valuation analysis to vulnerability by applying the VRIP (Vulnerability Resilience Indicator Prototype) model.

One of the studies conducted by Miladan [10] to analyze the vulnerability of the coastal area of Semarang City to climate change, especially the problem of rising sea levels that aggravate floods and tides in the region. Then there is also research conducted by Suhelmi [7], regarding dynamic models of flood vulnerability and tidal inundation in low-lying areas. While the research conducted by Brenkert and Malone [19], created a model that could assess the vulnerability of states in India and made a VRIP model based on several indicators, namely physical, social, and ecological conditions.

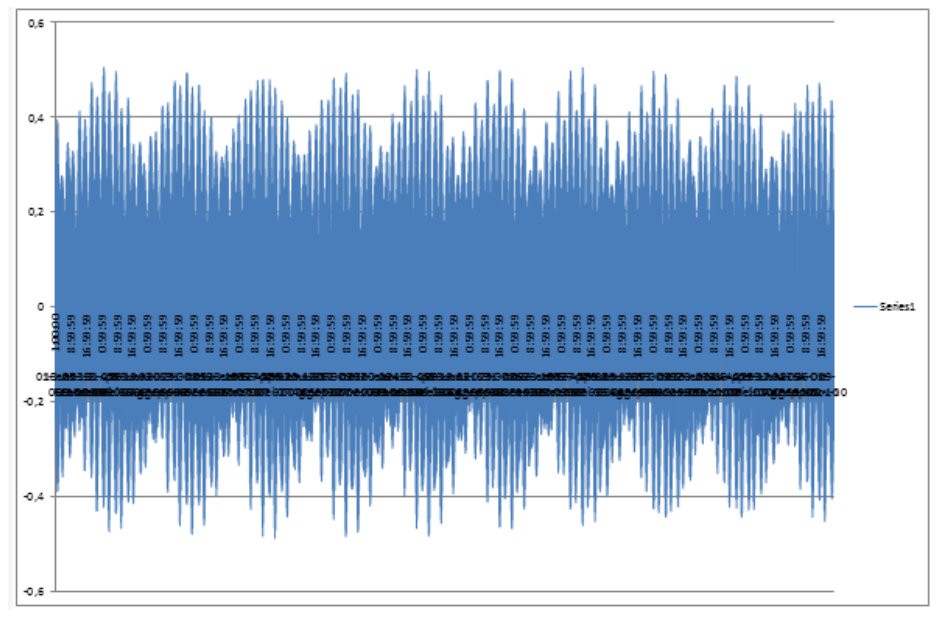

Fig. 3. Tidal Flood in Semarang City in 2006-2011

(Source: Data Processing, 2019)

According to Figure 3, tidal flood data fluctuation occurred in Semarang City over the period 2006 to 2011 taken around Semarang Port on 18 measuring stations. Overall, the tidal flood that 
occurred in Semarang City had increased by about $0.4 \mathrm{~cm} /$ year while the depreciation by about $0.4 \mathrm{~cm} /$ year as well, so the average difference was around $0.1 \mathrm{~cm} /$ year. The increase and decrease are almost the same so it can be said that the tides that occur in the city of Semarang are insignificant, so other methods are needed to determine the incidence of tidal floods that occur in Semarang city.

According to some previous studies, the tidal flood phenomenon that occurred in Semarang City was caused by climate change or sea-level rise and also land subsidence. This research will prove that the flood phenomenon occurred is not caused by the tidal flood. Digital Elevation Model (DEM) data processing and study of shoreline changes and loading around the Semarang coast to see tidal flood development so that tidal flood data is generated which will then be assessed with changes in coastline to land subsidence.

This research using GIS analysis is carried out to obtain the elevation change that is processed based on DEM data and data on the rate of change in land subsidence. Before carrying out further processing, it is necessary to pay attention to each scale on each spatial data used. Every spatial data used must have the same scale to overcome errors in its processing. The scale of the map and the spatial resolution are very important. To choose an equivalent image for mapping there is a mathematical formula that was invented by Wado R. Tobler in 1987. He stated, "For the denominator of the map scale with 1000, the equivalent image resolution is half of the result of the division".

In the initial stage, DEM classification is performed to determine the class of altitude region in the study area. Furthermore, the extraction of coordinate information and area altitude information is carried out by distributing points sampling evenly in the Research Area and Semarang City. This following map of elevation points and altitude areas (Figure 4a) and maps of land subsidence rates (Figure 4b) in the study area and Semarang City.

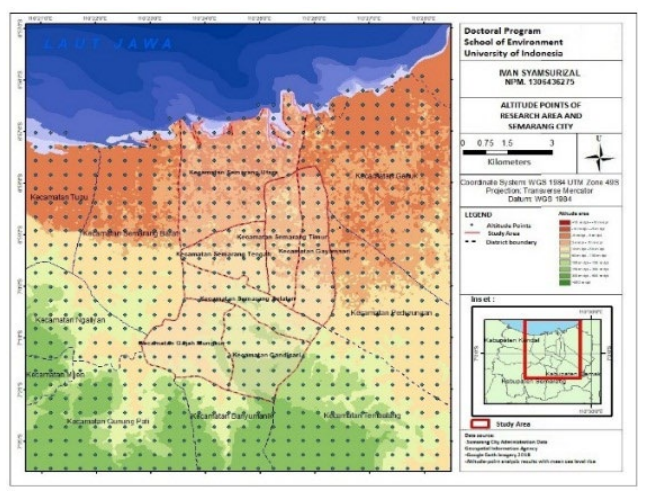

(a)

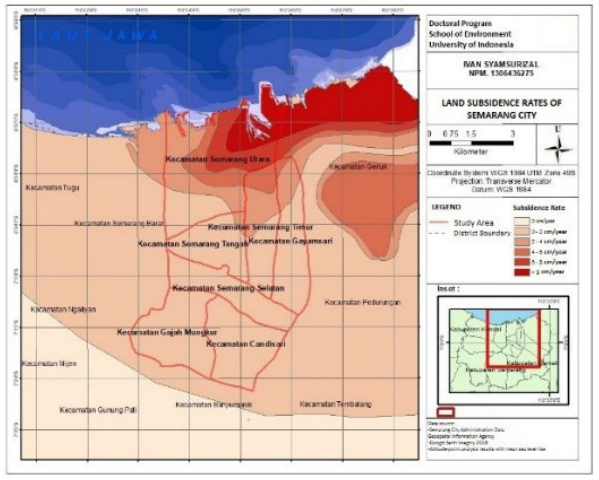

(b)

Fig. 4. (a) elevation points and altitude areas; (b) land subsidence rates (Source: Syamsurizal, 2019)

After the elevation is in accordance with the decline in a certain year, interpolation of these points is carried out to obtain the area affected by tidal flood. Tidal flood prediction is generated from the result of an overlay between elevation data (DEM) and Land Surface Depth Rate Data. These following maps showing the results of the precision in the Tidal flood areas in 2018, 
2028, 2038 and 2048 (Figure 5a) and the predicted expanse of the position of historic buildings or historical areas of the Semarang City (Figure 5b).

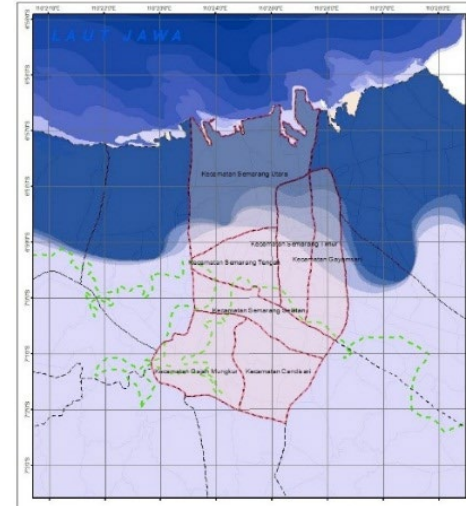

(a)

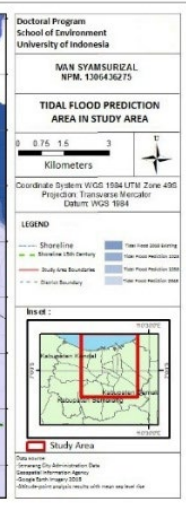

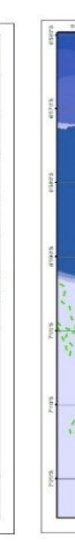
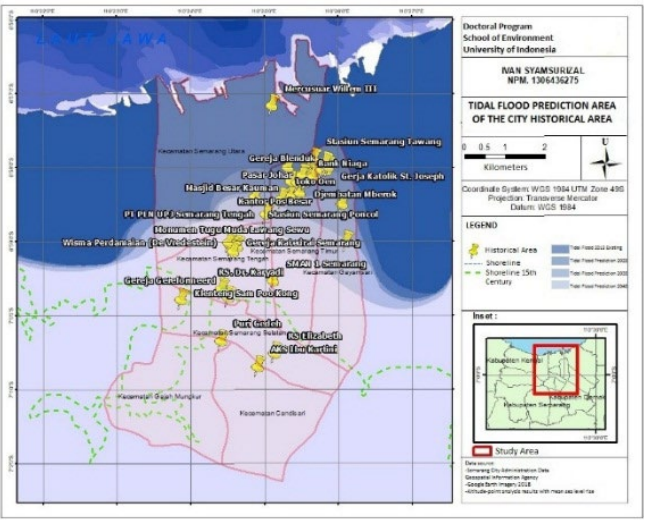

(b)

Fig. 5. (a) Tidal Flood Regional Prediction in Research Areas 2018, 2028, 2038, and 2048;

(b) Tidal flood Regional Prediction of the City Historical Area

(Source: Syamsurizal, 2019)

Based on the modelling in Figure 5a and Figure 5b, it can be seen that from a total of 7 research subdistricts areas, tidal flood is predicted to occur in 40 years in 4 sub-districts, in the northern part of the coastal area of the city of Semarang which was affected by tidal floods, it is directly facing the coastline. In the south and central part of the coast of Semarang City, the part affected by tidal flood is the historical area of the Old City while in the western part of the coast of Semarang City, the area affected by tidal flood is the area of cultivation areas such as ponds, then in the east part of it is a settlement area.

The phenomenon of tidal flooding is caused by a shift in the coastline as a result of anthropogenic pressure as if pushing the return of the coastline or disappearance of the existing land (reclaiming the area by the sea). Changes in the coastline around the city of Semarang are influenced by natural factors and the impact of development in the coastal area by human activities. Loading the shoreline shift is found in 5 sub-districts based on the study area. After calculated using the GIS application, Table 3 shows the prediction of the extent of the tidal flood that will occur in the study area in 2018, 2028, 2038, and 2048.

Table 3. Prediction of The Extent of The Tidal Flood in Research Areas 2018, 2028, 2038, and 2048

\begin{tabular}{ccrrr}
\hline Year & \multicolumn{4}{c}{ Districts } \\
& $\begin{array}{c}\text { North Semarang } \\
(\mathrm{Ha})\end{array}$ & $\begin{array}{c}\text { East Semarang } \\
\text { (Ha) }\end{array}$ & Gayamsari (Ha) & $\begin{array}{c}\text { Central } \\
\text { Semarang (Ha) }\end{array}$ \\
\hline 2018 & $1.042,81$ & 50,04 & 53,85 & 0 \\
2028 & $1.134,63$ & 101,45 & 118,06 & 0 \\
2038 & $1.163,75$ & 153,88 & 192,83 & 0 \\
2048 & $1.271,76$ & 247,93 & 310,62 & $4 ., 13$ \\
$\begin{array}{l}\text { Speed of } \\
\begin{array}{l}\text { Change in Area } \\
\text { (ha)/ 10 years }\end{array}\end{array}$ & & & & 1,37 \\
\hline
\end{tabular}

(Source: Syamsurizal, 2019) 
Based on Table 3, from 2018 to 2048 the total area affected by tidal floods in each affected subdistrict experienced an increase in the area each year. North Semarang is the most widespread sub-district affected by tidal floods with the speed of change in the area of the second-fastest tidal flood area of 7.6 hectares/year with the largest area of tidal floods. Meanwhile, Central Semarang District has the lowest rate of change, only 0.13 hectares/year and with the smallest tidal area among 4 areas affected by the tidal flood in the study area.

\section{Conclusion}

Semarang Vulnerability to disasters of the tidal flood is not significantly caused by the phenomenon of water level rise the sea that occurs due to the phenomenon of climate change or global warming. The Historic area which is the identity in the formation of Semarang City is not only located in the Kota Lama area as determined by Government but is a delineation of the area formed by buildings that have historical value. The results showed that the historical area of Semarang City is in 7 sub-districts. After modeling, Historical areas are proven to have contributed to the formation of City resilience. North Semarang is the most widespread district affected by tidal floods with the speed of change in the area of the second-fastest tidal flood area of 7.6 hectares/year with the largest area of tidal floods. Meanwhile, Central Semarang District has the lowest rate of change, only 0.13 Hectares /Year and with the smallest tidal area among 4 areas affected by tidal floods in the study area.

Referring to the conclusions obtained from the results of the research, the advice is given is the development of a city, as far as possible consider the carrying capacity of its environment, where one of them is to see and study the history of the formation of the city itself. Utilization of the space created by sedimentation should not be used to accommodate dense human activities but should be limited and it would be better to use it for green open areas or conservation areas. The Old City Region of Semarang, as a historical area of the city, needs to be developed further so that all buildings that have historical value in the formation of Semarang City can be saved. This is believed to contribute to the overall sustainability of the City of Semarang. For this reason, the development of the concept of Specific National Strategic Areas (KSNT) in the historical area of Semarang City is one of the right choices in the effort to maintain the sustainability of Semarang City which has potential as one of World Heritage. The Development of the Conceptual Model of Regional Interest for Urban Sustainability in Semarang City needs to be further developed using the participation and community perception variables related to the use of historical values to build city resilience.

\section{References}

[1] Law of the Republic of Indonesia Number 27 of 2007 concerning Management of Coastal Areas and Small Islands

[2] Marfai, M.A. dan King, L.: Tidal Inundation Mapping Under Enhanced Land Subsidence In Semarang, Central Java Indonesia. Environmental Geology. pp. 1507-1518 (2008a)

[3] Aerts, J.; Bowman, M.; Dircke, P.; Major, D.; dan Marfai, M.A.: Connecting Delta Cities, About Global Coastal Cities and Future Chalanges. VU University Press, Amsterdam, The Netherlands. (2009)

[4] Marfai, M.A.: The hazard of coastal erosion in Central Java Indonesia: an overview". GEOGRAFIA, Malaysia Journal of Society and Space. pp. 1-9 (2011) 
[5] Pallewatta, N.: Impacts of Climate Change On Coastal Ecosystems in the Indian Ocean Region. Coastal Zones and Climate Change, New York: The Henry L. Stimson Center. pp. 3-16 (2010)

[6] Karana, R.C. \& Suprihardjo, R.: Mitigasi Bencana Banjir Rob di Jakarta Utara. Jurnal Teknik ITS. pp. C31-C36 (2013)

[7] Suhelmi, I.R., Fahrudin, A., Yulianda, F. \& Nuitja, I.N.S.: Dynamic Model of Flood and Tidal Inundation Vulnerability in Lowlying Area, Case Study at Semarang. Geomatika. pp. 56-66 (2010)

[8] Pellikka, H., Leijala, U., Johansson, M.M., Leinonen, K. \& Kahma, K.K.: Future probabilities of coastal floods in Finland. Continental Shelf Research. pp 32-42 (2018)

[9] Nugroho, S.H.: Prediksi Luas Genangan Pasang Surut (Rob) Berdasarkan Analisis Data Spasial di Kota Semarang, Indonesia. Jurnal Lingkungan dan Bencana Geologi. pp. 71-87 (2013)

[10] Miladan, N.: Kajian Kerentanan Wilayah Pesisir Kota Semarang Terhadap Perubahan Iklim (Doctoral dissertation, Universitas Diponegoro). (2009)

[11] Suhelmi, I.R.: Valuating Semarang Coastal Vulnerability Due to Sea Level Rise Using Composit Vulnerability Index. Jurnal Segara. pp.97-106 (2012)

[12] Fauziah, A.N.: Kajian Kerentanan Iklim: Sebuah Penilaian Kembali di Wilayah Pesisir Kota Semarang. Jurnal Pembangunan Wilayah \& Kota. Pp. 316-329 (2005)

[13] Yesiana, R., Yuniartanti, R.K. \& Wulansari, A.: Pengelolaan Kawasan Pesisir Kota Semarang: Sebuah Potret Berkelanjutan. CoUSD Proceedings. pp. 221-227 (2015)

[14] Syamsurizal, I, Patria, M.P., Harmantyo, D.: Semarang City Tidal Floods or Geographical Phenomenon. Indonesian Journal Geography (Submitted). (2019)

[15] Brenkert, H., Champ, P. and Flores, N.: Mitigation of wildfire risk by homeowners. Res. Note RMRS-RN-25. Fort Collins, CO: US Department of Agriculture, Forest Service, Rocky Mountain Research Station. pp. 25 (2005a)

[16] Lam, N.S.N.: Spatial interpolation methods: a review. The American Cartographer. pp. 129-150 (1983)

[17] Lam, N.S.N.: Geospatial Methods For Reducing Uncertainties In Environmental Health Risk Assessment: Challenges And Opportunities. pp. 942-950 (2012b)

[18] Government Regulation No. 26 of 2008 concerning National Spatial Planning

[19] Brenkert, A. L. dan Malore, E. L.: Modelling Vulnerability and Resilience to Climate Change:

Case Study in Indian States. England: Cambridge University Press Climate Change. (2005b) 